\title{
Andragogie - 'n moontlike oplossing vir kerklike onderrig aan volwassenes in 'n multikulturele situasie
}

M J du P Beukes
Sentrum vir Teologiese Navorsing en Toerusting

Universiteit van Pretoria

\begin{abstract}
Androgogy - a possible solution to the catechism of adults in a multicultural situation

Multicultural education has become a world-wide phenomenon. International communication has made the world smaller, and multicultural education has become a need which every country, nation and church has to address. A lot has happened on the political and ecclesiastical fronts in South Africa since 1990. The division between peoples due to apartheid has largely disappeared in some urban circles. Multicultural church services created a challenge to the Nederduitsch Hervormde Kerk van Afrika as well. This article is an attempt to demonstrate that andragogy is a possible solution to the catechism of adults in such a way that neither social groups nor a specific church loses its identity.
\end{abstract}

\section{AKTUALITEIT VAN DIE TEMA}

Multikulturele onderrig het 'n wêreldwye verskynsel geword (Louw 1981:3). Sowel die Wêreldraad van Kerke as die Wêreldbond van Hervormde Kerke is besig met studie en navorsing in hierdie verband (Vroom 1995:3). Vanweë internasionale kommunikasie het die wêreld klein geword en het multikulturele onderrig 'n saak geword wat aan elke land, volk en kerk se deur klop (Lynch 1983:11).

Sedert Februarie 1990 het daar op die politieke vlak geweldige ontwikkelinge in Suid-Afrika plaasgevind. Die grense tussen volke het in sekere stedelike gebiede verdwyn. Vrye assosiasie het 'n alledaagse verskynsel geword. Apartheid is wetlik opgehef. Op 23 Mei 1994 word 'n einde gemaak aan 'n etnișerende onderwysbeleid toe een Nasionale Departement van Onderwys ingestel is. 'Die nuwe multikulturele SuidAfrika is tans vir almal aan die ontluik' (Viljoen 19:20). Van die kerk se lidmate woon in hierdie Suid-Afrika. Sommige se locus standi et vivendi het 'n multikulturele een geword. Hierdie daaglikse kruiskulturele kommunikasie is vir die kerk 'n besondere geleentheid om met die evangelie by mense uit te kom. Vir hierdie gespreksgeleentheid kan die andragogie nuttige riglyne bied. 
Waar die kerk se beleid oor lidmaatskap en erediensbywoning in die verlede in 'n baie groot mate belemmerend was vir multikulturele skakeling, verdwyn hierdie belemmering as die Nederduitsch Hervormde Kerk op sy Algemene Kerkvergadering van 1995 besluit dat multikulturele bediening in evangelisasiegemeentes moontlik is en dat die Hervormde Kerk nie meer voorskriftelik wil wees oor wie die kerk se eredienste mag bywoon nie (AKV 1995:48, 100). Hierdie besluite maak dit dringend noodsaaklik dat die Hervormde Kerk sal besin oor die wyse waarop ook onder andere onderrig in 'n multikulturele milieu kan plaasvind.

In 1995 besluit die South African Broadcasting Corporation (SABC) om nie meer net eredienste en oordenkings van Christelike kerke uit te saai nie, maar van alle godsdienste in Suid-Afrika. Dit lei tot deurlopende nadenke en gesprek met mense van ander godsdienste en kulture. Die waarheidsvraag en veral die vraag oor hoe om dit te hanteer, is voortdurend op die tafel (Doeser 1983:26).

In sulke omstandighede kan die lede van 'n bepaalde volk of groep nie meer beskryf word as 'n monokulturele gemeenskap nie (Viljoen 1995:20). Boshoff (1990:15) toon aan dat daar nie meer uniforme lidmate met net een waardesisteem bestaan nie. Diversiteit het 'n algemene verskynsel geword. Vir die postmoderne denke is hierdie diversiteit volkome aanvaarbaar (Vorster 1994:3). Uit bogenoemde kan die afleiding gemaak word dat multikulturaliteit in 'n groot mate 'n normale verskynsel in feitlik elke gemeente van die kerk geword het en dat die andragogie selfs vir die gewone gemeentelike bediening van groot nut kan wees.

\section{NOODSAAKLIKHEID VAN KATEGESE AAN VOLWASSENES}

Die noodsaaklikheid van kerklike onderrig aan al die gelowiges, is baie sterk deur die Kerkhervormers aangevoel. Dit het aanleiding tot die opstel van verskillende kategismusse gegee. Hierdie kategismusse was nie net bedoel vir die kinders nie, maar ook vir die volwassenes (Beukes 1983:54).

$\mathrm{Na}$ die Reformasie het daar ' $\mathrm{n}$ totale verarming van die kerklike onderrig plaasgevind. Enersyds is die beperking te wyte aan die beperking van die onderrig tot die kognitiewe vlak en andersyds vanweë die misverstand dat onderrig ophou sodra belydenis van geloof plaasgevind het. Kerklike onderrig hou eers die dag op wanneer iemand sterf:

Den catechismus geleerd te hebben betekent geen afsluiting van het kerklijk onderricht, alsof de catechese met de aanneming en bevestiging ophoudt, maar integendeel begin, begin van eigenlijke onderricht in de rechte en zuivere kennis Gods 'Laten wij daarom het eerste onderwijs 
aangaande Christus laten rusten en ons richten op het voikomene' (Heb 6:1). Hiermee is het ons nu wel duidelijk geworden dat het kerklijk onderricht, nooit ophoudt. Het is een bestaansvorm van het christelijk leven. Zonder een volharden bij het onderwijs der apostelen (Hand 2:42) is men geen christen. Het onderricht is onbegrensd. De leering en vermaning des heeren gaat door. Wij komen er niet af.

(Van Uchelen 1945:25)

Malan Nel (1994:26) het veral vanuit die behoefte van gemeentebou die noodsaaklikheid van voortgesette kerklike onderrig aangetoon. Gemeentebou is die kerklike aktiwiteit om deur middel van die bestaande kerklike kommunikatiewe geloofshandelinge en moontlike ander geloofshandelinge die gemeente te begelei om te wees wat dif reeds in Christus is. Hierdie bouwerk geskied altyd binne 'n kategetiese raamwerk. Elke profeet wat die bou-metafoor gebruik het, was besig om die volk te onderrig in die weë van die Here. Net soos in die Ou Testament, neem onderrig in die betekenis van die Nuwe-Testamentiese bou-metafoor 'n belangrike plek in (Hendriks 1987:20).

In heelwat kerke is die vraag sedert 1940 na die diakonia van lidmate op die tafel. Die vraag hoe lidmate hulle plek as medewerkers in die koninkryk van God kan inneem, het sedert Kraemer se Het vergeten ambt in de kerk - een van die kern besinningspunte in die geledere van die kerk geword. Sedertdien het lie vergete amp in baif kerke die centrale ambt geword (Bijlsma 1962:284). Uit Bybelse gegewens kan nie sonder meer 'n keuse gemaak word tussen geïnstitueerde amp en die diakonia van gelowiges nie (Pelser 1990:1-19). Die verhouding tuss n amp en lidmaat, soos dit in Efesiërs 4 na vore kom, is miskien die keuse wat die kerk moet maak met die oog op sinvolle bediening. Volgens Efesiërs 4:16 is die ampte gegee om die gelowiges vir hulle dienswerk toe te rus. Hieruit is dit duidelik dat daar tussen ampte en lidmate nie ' 7 statusverskil is nie, maar slegs ' $n$ funksieverskil ( $\mathrm{Nel} \mathrm{1986:33).} \mathrm{Om} \mathrm{sinvolle} \mathrm{diens-}$ werk in die wêreld te doen, het beide ampsdraers en lidmate deurlopende onderrig nodig. Van Uchelen (1945:8-16) het verskeie faktore aangetoon wat voortgesette onderrig aan lidmate noodsaaklik maak:

Die proses van sekularisasie met die daaruit voortvloeiende sekularisme het daartoe gelei dat die kerk sigself van die een lewensgebied na die ander onttrek en sigself in 'n hoekie wat nog net op Sondag funksioneer, gedryf het. Die kerk is nie net afgesluit van die wêreld nie, maar ook van Christus. Die kerk het in 'n sekere sin net oopgebly vir die eie regiemente en tradisies. Die kerk is so vasgevang in tradisies dat dit nie meer altyd die roeping nastreef nie. Hierdie situasie het gelei tot stagnasie en dood- 
bloei van baie gemeentes. Christenwees het verword tot 'n partikuliere onderneming wat verstik in vrome individualisme. Kennis en begrip hoe om koinonia te beleef en uit te leef, het verdwyn. Lidmate se besigwees met God en die wêreld roep by hulle talle vrae op. Hulle het behoefte aan onvervalste en duidelike antwoorde. Hulle vra na riglyne en grense. Veral in 'n twintigste-eeuse wêreld waar relativisme aan die orde van die dag is, vra 'n duidelike aantoon van dit waarop dit werklik aankom.

Hoewel onderrig inbegrepe is by al die werk van die kerk, vorm dit ook 'n selfstandige deel van die kerk se werk en vra dit genoeg tyd en aandag in gemeentes en op sinodale vlak. Dit vra 'n werkgroep vir kerklike onderrig in elke gemeente en 'n raad vir kerklike onderrig op sinodale vlak.

\subsection{VERKLARING VAN BEGRIPPE}

\subsubsection{Kultuur}

Dit gaan in hierdie paragraaf nie om 'n volledige uiteensetting van kultuur as sodanig nie, maar slegs om beskrywing van kultuur in soverre dit van belang is vir die bespreking van onderrig in ' $n$ multikulturele situasie.

Wanneer ons oor 'kultuur' praat, kan dit geskied vanuit die dissiplines van die sosiologie en die antropologie en dan in die besonder die kulturele antropologie. Die kulturele antropologie het veral 'kultuur' as studieveld. Die begrip 'kultuur' is aanvanklik gebruik as ekwivalent vir die begrip 'beskawing'. Albertyn (1974:369) beskryf kultuur as die aanduiding van die geheel van sedes, gewoontes, instellings, idees en gedragwyses, kuns, wetenskap, godsdiens en filosofie van 'n tyd, volk en groep. Kultuur fokus veral op die wisselwerking tussen ooreenkomste en verskille in gemeenskappe. 'Kultuur is 'n georganiseerde sisteem van simbole waardeur daar aan persone, dinge en gebeure spesifieke en sosiaal gedeelde betekenisse en waardes toegeken word. Spesifiek in die sin dat daar binne die sisteem geen twyfel oor die betekenis en waarde bestaan nie. Sosiaal gedeel in die sin dat elke lid van die kultuurgroep dieselfde betekenis en waarde toeken' (Van Staden 1995:2). Opsommend kan gesê word dat kultuur 'n bepaalde groep, gemeenskap of volk se identiteit, selfverstaan en lewenswaardes beskryf. Veral Jarvis (1987:11) het daarop gewys dat leer en kultuur onlosmaaklik aan mekaar verbonde is. Leer is nie 'n psigologiese gebeure wat geisoleerd van die leerling se leefwerreld plaasvind nie. 'Indeed that is intimately related to that world and affected by it'. In aansluiting by Lawton stel hy: 'curriculum is a selection from culture, since education is one of the means whereby that culture is transmitted to the individual learner'.

Dit is belangrik om daarop te let dat kultuur en ras nie sonder meer gelyk aan mekaar is nie. Semanties gesien, verwys ras na die groot indelings van die wêreldbevolking in terme van fisiese en geestelike eienskappe. Kultuur aan die ander kant, 
verwys na die sisteem van simbole waarvolgens bepaalde waardes en betekenisse aan mense, dinge en gebeure toegeken word. Dit impliseer dat daar binne een etniese groep verskillende kulture kan voorkom of dat mense wat aan verskillende etniese groepe behoort, in 'n baie hoë mate dieselfde kultuur kan hê.

\subsection{Multikultureel}

In die lig van bostaande beskrywing kan onderskeid gemaak word tussen monokultureel en multikultureel. Monokultureel is die sisteem van simbole met betrekking tot mense, dinge en gebeure wat gemeenskaplik is aan 'n bepaalde, homogene sosiale gemeenskap.

Die begrip multikultureel, daarenteen, veronderstel meerdere sisteme van simbole wat betrekking het op mense, dinge en gebeure - dit wil sê, sisteme waarin verskillende waardes aan die sake toegeken is. Hierdie sisteme mag ooreenkomste vertoon, maar ook verskille. 'n Multikulturele gemeenskap is dus 'n gemeenskap wat nie kultureel homogeen is nie, maar verskeie kulture met hulle simboolsisteme insluit.

(Van Staden 1995:2)

Louw (1981:10) onderskei tussen vertikale plurale kultuur, horisontale plurale kultuur en kulturele pluralisme. Kulturele pluralisme is die bestaan van meer as een kultuur binne dieselfde staat en in dieselfde tyd. Vertikale of geïsoleerde kulturele pluralisme veronderstel dat verskillende groepe naas mekaar bestaan en dat elke groep 'n eie besondere leefwyse het; met eie gebruike, oortuigings, instellings, taal ensovoorts. Op grond van die feit dat groepe hulle eie taal, godsdiens, kultuur en leefwyse het, het groepe ook hulle eie religieuse, ekonomiese en opvoedinginstellings, sodat daar minimale interaksie tussen die verskillende kultuurgroepe is wat gevolglik gekenmerk word deur geslotenheid. Die sogenaamde horisontale pluralisme verwerp skeiding sowel as assimilasie van kultuurgroepe. Die voorstanders van horisontale pluralisme probeer om 'n brug te slaan tussen die twee teenoorgestelde pole deur verskillende kultuurgroepe sekere basiese instellings soos skole, hospitale, kerke, werkgeleenthede ensovoorts te laat deel.

Beide vertikale en horisontale pluralisme is meer as bekend in Suid-Afrika. In hierdie artikel sal sonder meer uitgegaan word van 'n neutrale standpunt, naamlik dat kulturele pluralisme en 'n multikulturele samelewing in veral sekere stedelike gebiede in Suid-Afrika 'n werklikheid is wat nie meer weggeredeneer kan word nie. 


\subsection{Multikulturele onderrig}

Multikulturele onderrig beteken meer as net onderrig in 'n multikulturele situasie. Viljoen (1995:1) beskryf dit as 'die totale transformasie van die skoolomgewing met as einddoel die skep van onderrig en leergeleenthede afgestem op die behoeftes van leerlinge uit diverse kulturele, taal, sosio-ekonomiese, politieke, ens. agtergronde'.

Multikulturele onderrig is nie 'n nuwe verskynsel op die gebied van die onderwys nie. Louw (1981:12) het 'n besondere studie van multikulturele onderrig in die Verenigde State van Amerika en Brittanje gemaak. Hy kom tot die gevolgtrekking dat dit in die twee lande die algemene wyse van onderrig geword het, tot so 'n mate dat 'multicultural education' daar 'n terminus technicus geword het om 'n bepaalde soort onderwys te beskryf. Dit word reeds etlike dekades lank bestudeer en het gevestig geraak as een van die aanvaarbaarste benaderings tot ondewys in kulturele diverse samelewings (Viljoen 1995:2). Hierdie 'onderwys' poog doelbewus om mense van verskillende volke en kulture te verenig. Dit het daartoe gelei dat Lynch (1992:1-25) 'n pleidooi gelewer het vir 'education for citizenship in a multicultural society'.

In hierdie artikel word multikulturele onderrig nie gebruik as terminus technicus vir beskrywing van 'n bepaalde soort onderwys nie, maar in die eenvoudigste vorm, naamlik slegs as onderrig aan mense wat hulle in 'n multikulturele situasie bevind. Onderrig word nie hier gesien as 'n middel om mense polities of sosiaal te versoen nie, maar as 'n middel om die Woord van God by mense uit te bring.

\subsection{Onderrig}

In die woord 'onderrig' hoor 'n mens baie duidelik die grondbetekenis van 'gericht worden onder iets' (Van Uchelen 1945:18). Die mens word gerig onder die Woord van God. Hierdie rig onder die woord van God, is baie meer as net die bybring of die aanvaarding van 'n klompie geloofsfeite. Hierdie rig betref die hele mens, 'die zich gedurende zijn geheele leven buigt onder het Woord Gods en in den weg van Gods inzettingen wil wandelen' (Van Uchelen 1945:20).

Net soos vir Van Uchelen, is kerklike onderrig vir Firet (1977:55) baie meer as net die bybring van kennis. Volgens hom realiseer God sy heil deur na die mens in die gestalte van 'kerugma, didache en paraklese' te kom. Hoewel hierdie drie modi onlosmaaklik aan mekaar verbonde is, is elkeen tog 'n selfstandige gestalte van die kerklike bediening. In die Ou Testament het didache die betekenis van inwy in die verhaal van Jahwe en sy volk. Die kind word in die vertelling persoonlik by hierdie verhaal betrek, 'zo dat hij het gaat verstaan als zijn verhaal. Hij leert wij zeggen en wij te beleven het wij van het verbond' (Firet 1977:72). Hierdie-weg vra dat gelowiges hulle inbegrepenheid op God se pad sal glo, maar dat hulle ook die tora sal onderhou wat van 
hulle gehoorsaamheid aan God in elke lewensfeer vra. Hierdie weg kom nie self in diekind se lewe in nie, maar moet geleer word. In die Nuwe Testament word die didache in die nouste verband met Jesus Christus gebring. Dit is deel van die proses van dissipelsmaak (Matt 28:19). Dit is die nadere ontvouing van die heilsgebeure. Dit ontvou die sin en die konsekwensies van dit wat in die kenugma aan die lig gekom het. Dit wys die implikasies aan van die groot heilsgebeure in Jesus Christus. Firet wil dat die didache nog meer toegespits verstaan word. Hy bring dit in direkte verband met dissipelskap. Dissipelskap beteken vir hom die nouste moontlike relasie met Jesus Christus. Didache beteken daarom vir hom begeleiding van verbondskinders om hulle verlossing van Jesus Christus alleen te verwag en om Hom in alles gehoorsaam te wees. So gesien, is die didache baie meer as net leerstellige of etiese onderrig. Die didache is: "Glaubenshilfe als Lebenshilfe", maar men zou tegelijk ook moeten zeggen “Lebenshilfe als Glaubens-hilfe"' (Firet 1977:90).

Net soos Firet, bring Dingemans (1986:233) kerklike onderrig en dissipelskap in die nouste verband met mekaar. Die kerklike onderrig beteken vir hom primêr om jongelinge na Jesus Christus te lei, sodat hulle op hulle eie wyse in noue samehang met die geloofsgemeenskap Jesus Christus sal volg, 'kerk en samelevening op een geëngageerde en kritische wijse zullen willen dienen en tot eigen standpunt, ervaring en engagement ten aanzien van het geloof kunnen komen'.

In die Prakties-Teologiese denke het daar met betrekking tot die kerklike onderrig die afgelope aantal jare groei en ontwikkeling plaasgevind. Kategese is besig om weg te groei van 'n eenrigting, outoritêre, amptelike, skoolse onderrig in 'n verskuilde hoekie slegs op Sondae met die oog op die regte leer van die kerk. Dit is besig om 'n familiale, gemeentelike kommunikatiewe geloofshandeling te word, met die oog op die regte verhouding met God wat tot uitdrukking kom in geloofshandelinge en in die gemeente en in die wêreld. Dit kom tot stand deur die Woord en die Gees van God (Beukes 1995:12). As deel van die totale didaskein van die kerk vorm dit 'n eenheid met die ander kommunikatiewe geloofshandelinge (Pieterse 1993:2) en is dit ingebed in al die kommunikatiewe geloofshandelinge van die kerk (Prins 1992:139). Dit hou nie op na belydenis van geloof nie. Dit word 'n lewenstaak van die lidmaat. Dit is 'een permanent leren' (Schippers 1982:13). Die primêre bron van die kategese is nie meer die belydenisskrifte nie, maar die Bybel. Die kerklike onderrig wil eerder in diens aan God regdenkende mense vorm.

In hierdie artikel word nie in die besonder gefokus op onderrig van volwassenes in 'n eng onderrigsituasie nie, maar onderrig in die breë gesien, soos dit hier bo beskryf is. 


\subsection{Andragogie}

\subsubsection{Oorsprong van die dissipline}

Die term andragogie is vir die eerste keer in 1835 deur die Duitser Alexander Kapp gebruik. In 1921 gebruik van Enchevort die term in Holland en vandaar versprei dit oor Europa (Simpson \& Lessing 1991:4). Dit was veral in die Verenigde State van Amerika waar die begrip en die saak van andragogie gegroei en gebloei het. Volgens die Davenports het Anderson en Lindeman die begrip andragogie aan Amerika voorgestel, maar dit was eers Knowles wat hierdie teorie tot praktyk omskep het en dit algemeen bekend gemaak het: 'Knowles should more properly be acknowledged for reintroducing and popularizing andragogy in the United States. His publications and presentations are largely responsible for the developement of andragogy as legitimate approach to adult education' (Davenport \& Davenport 1985:6).

Andragogie is dikwels baie breed gesien en beskou as sinoniem vir volwasseopvoeding, terwyl andragogiek die dissipline sou beskryf. In die algemeen word andragogie bloot gesien as onderrig aan volwassenes. Simpson (1992:100) gee die volgende definisie van andragogie: 'Andragogie is 'n onderrigwyse waarvolgens mense, aan die hand van aangebode leergeleenthede, die geleentheid gebied word om hulle potensiaal te ontdek en te ontwikkel sodat hulle hulle rol binne die ruimte van werk, gesin en gemeenskap met groter bevrediging kan vervul'. Simpson se eie navorsing en ander navorsing bring egter aan die lig dat andragogie nie beskrywend is van alle onderrig nie, maar spesifiek die onderrig van volwassenes.

Hierdie artikel is nie 'n poging om elke aspek met betrekking tot andragogie te beskryf en te evalueer nie. Dit wil slegs aantoon hoe die basiese beginsels van die andragogie deur die kerk benut kan word vir onderrig in 'n multikulturele situasie.

\subsubsection{Aanleidende oorsake vir die ontwikkeling van die andragogie}

Voor die koms van die andragogie is die onderrig- leergebeure in 'n groot mate deur die volgende leerteorieë se uitgangspunte oorheers: die assosianistiese, funksionalistiese, organistiese, kognitiewe en humanistiese (Dingemans 1986:182). Enersyds het didaktici en opvoedkundiges een bepaalde leerteorie benut of slegs een verhef tot die een en die al. Andersyds is bepaalde komponente van elkeen geneem en saamgevoeg om 'n basis vir onderrig te vorm.

Dit was veral Knowles (1984: 5-8) wat die meeste uitgangspunte van die bestaande leerteorieë as vertrekpunt vir onderrig aan volwassenes baie sterk afgewys het. Vir hom is dit onaanvaarbaar dat resultate wat met diere se gedrag verkry is, sonder meer op mense toegepas kan word. Dit is net so onaanvaarbaar dat leer wat as reaksie op 
stimuli getipeer word, as normatief beskou kan word. Hierdie uitganigspunte het die mens gedegradeer tot 'n wese sonder ervarings en behoeftes. Die verskillende bestaande leerteorieë se uitgangspunte het volgens Knowles gelei tot pedagogiese modelle met die volgende leemtes:

* Daar word van leerders feitlik geen vooraf kennis of ervaring verwag nie. Vooraf kennis of ervaring sou kon lei tot sogenaamde te hoë insette deur die leerlinge self.

* Daar bestaan geen ruimte vir selfstandige leer en navorsing nie.

* Leerders word volkome as ondergeskik en afhanklik van die onderwyser beskou.

* Opdragte word gegee en daar word van leerlinge verwag om dit sonder enige kommentaar uit te voer.

* Leerders se ervaring en individuele behoeftes word op geen manier in berekening gebring nie. Almal word oor dieselfde kam geskeer.

* Leerders betree ' $n$ onderwysgeoriënteerde en leergesentreerde klimaat.

* Vaste leerinhoude word voorgeskryf en die leerling het geen aandeel in die seleksie daarvan nie.

* Leergeleenthede is beperk tot 'n eenrigting outoritêre lesingstyl.

* Onderrig word gegee sonder duidelik geformuleerde doelstellings en doelwitte.

* Die klem word in die onderrig op die kognitiewe gelê. Die affektiewe en die psigomotoriese word nie in berekening gebring nie.

* Doelwitte word nie geëvalueer nie, maar wel sekondêre kognitiewe aspekte.

* Motivering is nie 'n integrale onderdeel van die leergebeure nie, maar is ekstern van aard en druk tot prestasie word van buite afgedwing.

Die gevolg van so ' $n$ benadering is dat leerders en veral volwassenes 'n al groter wordende wrewel en weerstand teen elke vorm van onderrig ontwikkel (Simpson 1992:86).

Knowles oordeel dat daar 'n skerp onderskeid tussen die leer van kinders en die gedrag van diere gemaak moet word. Hy sluit sterk by die humanistiese leerteorieë aan wat die mens uit 'n holistiese hoek as ' $n$ sosiale wese met ervarings, behoeftes en vrese beskryf (kyk Simpson 1992:85). Selfs die kind en die volwassene verskil as leerders radikaal van mekaar. Volgens Knowles (1973:45-49) onderskei die volgende tipiese kenmerke die volwassene as leerder van kinders:

* Die volwassene se selfkonsep is baie sterk selfgerig teenoor die kind wat sterk in 'n milieu van afhanklikheid funksioneer. In die leersituasie is die kind bereid om sonder meer te aanvaar, terwyl die volwassene 'n sê wil hê in selfs dit wat van hom verwag word. 
* Vir volwassenes is ervaring deel van hulle bestaan. Ervaring is vir kinders in 'n baie groot mate iets wat van buite met hulle gebeur. Die kind is hoegenaamd nie daarop ingestel dat uit sy of haar ervaring geput moet word nie. Volwassenes ervaar dit uiters negatief as hulle ervaring in die onderriggebeure nie as 'n helpende faktor benut word nie.

* Die kind is in 'n groot mate 'n wese wat sonder kommer leef en sien die onderriggebeure daarom nie as ' $n$ besondere geleentheid om antwoorde te bied op die hier en die nou van sy of haar eksistensie nie. Volwassenes se deurlopende ervaring van krisisse lei tot die deurlopende soek na antwoorde in die onderriggebeure wat vir hulle konkrete situasie toepaslik is.

* Bereidheid tot leer hang by die volwassene in 'n baie groot mate af van die bevrediging van behoeftes soos bevordering, selfaktualisering, innerlike verryking en beter rolvervulling. Kinders word hoofsaaklik gedryf deur ekstrinsieke motiveerders, soos onder andere hulle ouers.

Gaandeweg het Knowles (1984:5) bogenoemde verskille in 'n teorie saamgevat wat hy as 'a system of concepts' vir volwasse-onderrig beskryf. Samevattend omskryf Simpson (1992:87) Knowles se teorie soos volg:

* Volwassenes het ' $n$ behoefte om te weet waarom hulle iets moet leer.

* Volwassenes openbaar ' $n$ behoefte aan selfgerigtheid.

* Volwassenes beskik oor ervaring, kwalitatief en kwantitatief.

* Volwassenes openbaar leergierigheid, sodra lewens- of werksomstandighede dit vereis.

* Volwassenes betree 'n leergeleentheid met 'n probleem-, taak- of lewensgesentreerdheid.

* Volwassenes word deur beide ekstrinsieke en intrinsieke motiewe gemotiveer om te leer.

\section{BREËRE BESKRYWING VAN DIE ANDRAGOGIE}

\subsection{Algemene uitgangspunte}

Die meeste beoefenaars van die andragogie gebruik Knowles se 'system of concepts' as vertrekpunt (kyk Simpson 1992:86). Daar word egter nie by hierdie vertrekpunt volstaan nie. Hoewel dit gewoonlik nie altyd uitdruklik erken word nie, aanvaar die be- 
oefenaars van die andragogie dieselfde kurrikulumteorie as die gewone didaktici. Daar is egter 'n radikale verskil, veral omdat deeglik met die volwassene as leerder rekening gehou word (Richards 1975:250).

Die basiese kurrikulumteorie van Ralph Tyler en later onderskeidelik verfyn deur Kruger, Kuiper, Dingemans en Beukes (Beukes 1994:230) dien vir die andragogie as basismodel (kyk ook Peterson 1984:73). Dit beteken dat in hierdie onderriggebeure die volgende verreken moet word:

* Situasie-ontleding: Hier moet veral die volwassene as leerder, sy/haar leefwêreld en die onderwyser van die volwassene verreken word.

* Doel en doelwitte wat bereik wil word.

* Seleksie van inhoude met die oog op realisering van die doelwitte.

* Leergeleenthede wat veral geskik sal wees vir volwassenes.

* Evaluasie om te bepaal in watter mate die doelwitte gerealiseer het.

\subsection{Situasie-ontleding}

\subsubsection{Die volwassene as leerder}

Aangesien hierin die basiese verskil tussen onderrig aan volwassenes en kinders lề, sal op hierdie aspek besondere klem gelê word.

Voor 1970 is volwassenheid in 'n baie groot mate gesien as 'n 'non development period' (Tight 1983:107). Die volwasse stadia van menswees is beskryf as stabiel, onherroepbare afname of afname met kompensasie (Schaie, in Louw et al 1984:414). Gerdes voeg hierby ' $n$ vierde model naamlik die van deurlopende ontwikkeling. Volgens haar kan 'n volwassene 'n stadium van stagnasie bereik, maar die mees algemene is eerder ' $n$ lewenslange, deurlopende ontwikkeling (Gerdes, in Louw et al 1984:414). Individuele verskille kom van geboorte af voor, sodat mense meer anders as eenders is (Olivier 1982:36). Hierdie verskille neem nie af in die stadium van volwassenheid nie, maar neem eerder toe. Elke volwasse leerling moet daarom as uniek gesien word (Gerdes, in Louw et al 1984:414).

Vroeër is geoordeel, as daar wel sprake van ontwikkeling by volwassenes is, is dit in 'n meganistiese paradigma. Volgens hierdie teorie bepaal faktore wat inherent aan die menswees spesie is, die ontwikkeling. Tans word ontwikkeling van volwassenes baie meer in 'n kontekstuele paradigma gesien. Met Erikson en Kohlberg se teorieë as uitgangspunte het Paula Allman (kyk Tight 1984:107-124) 'n besondere studie van die ontwikkeling van die volwassene gemaak. Beide se teorieë oor die ontwikkeling van die identiteit het groot invloed op Allman se dialektiese ontwikkelingsteorie gehad. 
Volgens Erikson is die ego of die identiteitsontwikkeling die resultaat van interaksie tussen psigologiese prosesse en die konteks gedurende die adolessensiejare. Hy plaas die klem op die psigologiese prosesse. Hierdie teorie van Erikson bied volgens Allman (kyk Tight 1984:115) die moontlikheid vir 'n teorie 'to create a sense of identity which is open to change and development'. Dit beteken dat bepaalde identiteitskenmerke wat reeds verwerf is, weer kan verdwyn en 'that what is not gained in the first instance can be gained'.

Kohlberg het in sy studie veral gekonsentreer op die morele ontwikkeling van die mens. Volgens hom beweeg ' $n$ mens se morele oordele van 'n pre-konfessionele, na 'n konfessionele tot 'n post-konfessionele. Waar Kohlberg hierdie teorie hoofsaaklik toepas op die ontwikkelingsfases van kinders, maak Allman (kyk Tight 1984:119) dit los van kinderfases en sien dit eerder as 'n proses wat gedurende ' $n$ mens se hele lewe an die gang is. Die beweging word volgens haar nie deur die ontwikkkelingsproses veroorsaak nie, maar deur die sosiale kontekste waarin mense hulle bevind. Pre-konfessioneel beteken in hierdie verband 'n feitlik blindelingse laat lei deur die konsepte van voorgeslagte en die gemeenskap waarin jy jou bevind. Konfessioneel beteken vir haar oni binne die grense van die oorgelewerde en die gemeenskap, selfstandige waardes te handhaaf. Post-konfessioneel beteken vir haar om oop te wees vir insigte en invloede van die hele wêreld. Volwassenes beweeg nie voort van die een fase na die ander nie, maar eerder heen en weer afhangende van die konteks waarin hulle hulle bevind.

In die lig van die verwerking van Erikson en Kohlberg se teorieë, maak Allman noodwendig die afleiding dat daar nie so iets bestaan soos 'n modelvolwassene nie. Elke volwassene moet net soos elke kind gesien word as mens in wording. Selfstandigheid en 'oopheid' is volgens haar die twee algemeenste kenmerke van volwassenheid. Andragogie is daarom eerder ' $n$ 'approach' as ' $n$ 'method'. Hoe hierdie mens op daardie oomblik is, moet verreken word in die onderriggebeure. Vir die praktiese onderriggebeure beteken dit noodwendig dat die onderwyser geen selfstandige besluit mag neem nie. Elke aspek van die onderriggebeure moet geskied volgens konsensus van die groep wat daarby betrokke is (Allman, in Tight 1984:120). Die volwasse leerder is daarom nie objek van die onderriggebeure nie, maar mede-subjek wat ten opsigte van al die aspekte van die onderrig medebepalend is (Beukes 1995:19).

Hoewel aanvaar word dat volwassenes, net soos kinders, meer anders as eenders is, is daar by hulle tog bepaalde einskappe wat ooreenstem. Navorsers onderskei verskillende fases van volwassenheid. Gerdes (in Louw et al 1984:415) ordeel dat oor die algemeen tussen vroeë volwassenheid 20 tot 40 jaar en midde-volwassenheid 40 tot 60 jaar onderskei kan word. Na hierdie periode tree die bejaarde fase in. Elkeen van 
hierdie fases word gekenmerk deur bepaalde eienskappe. Dit was veral die 'longitudinale' studie van Owens in 1966 en die dwarsdeursneestudie van Green in 1969 wat die besondere karakteristiek van elke fase op die tafel geplaas het (Gerdes, in Louw et al 1984:429-475). Op teologiese vlak het veral Fowler (1981:1-139) met sy navorsing op sogenaamde religieuse fases ook tipiese fasette van die volwasse se geloofslewe uitgespel. Op die vlak van onderrig aan volwassenes kan veral van Peterson se The christian education of adults, kennis geneem word (1984:49-56).

Die vroeë fase van volwassenheid staan bekend as die vestigingsfase. Gedurende hierdie fase moet veral baie opofferings gemaak word met betrekking tot gesin en beroep. Die meeste van die gesin se kinders word gebore wat veral deeglike insig in kinderopvoeding vra. Gehegtheid is 'n besondere ontwikkeling op sosiale vlak. Daar is ' $n$ sterk hunkering na hegte gesins- en vriendebande. Die nie-verbale intelligensievlakke bly konstant, terwyl die verbale vermoëns toeneem.

Dit bring mee dat op 'n hoë vlak gesprek gevoer kan word. Gould (in Gerdes 1984:469) verdeel die vroeë volwasse fase in drie fases, elkeen met eie tipiese kenmerke: 16-22 sentreer om onafhanklikswording; 22-28 die bevraagtekening van die self en lewensrolle en 37-43 as 'n tydperk van kritiese selfbeskouing, veral met betrekking tot waardes en lewenstyl.

Die middel-volwasse periode kan beskryf word as die jare van gevestigdheid. Op hierdie stadium is al die kinders van die gesin gewoonlik gebore. Die opvoeding van die kinders begin om 'n vaste patroon aan te neem. Die norme en waardes van die gesin is gevestig. Die stormagtige jare van die huwelik is grootliks verby. Die meeste doelwitte ten opsigte van die beroep is bereik. Hierdie fase word egter ook deur baie krisisse gekenmerk. Die volgende is waarskynlik die belangrikste: corgangsjare word bereik, kinders is in die adolessente fase, beroep, kerk en sosiale lewe vra baie hoë insette en die fase van die 'leë nes' word teen die einde van hierdie periode beleef.

Die biologiese verouderingsproses is ' $n$ werklikheid. Bejaardheid is daarom 'n natuurlike lewensfase wat op ' $n$ bepaalde stadium intree. Veroudering is ' $n$ normale deel van die lewensiklus van die mens en is op sigself nie 'n siekte nie. Moderne navorsing van die gerontologie het ' $n$ groot bydrae gelewer in die hantering van bejaardes (Coetzer 1988:1-35). Diskriminasie op grond van ouderdom is 'n feitlik algemene verskynsel: kinders neem vir hulle bejaarde ouers besluite; die gemeenskap beplan vir die bejaardes aktiwiteite waarby hulle moet inskakel, of hulle wil of nie; die kerk en die sosiale gemeenskap beskou hulle uitsluitlik as arbeidsveld en benut hulle hoegenaamd nie as arbeidsmag nie. Hierdie fase word in die besonder gekenmerk deur verliese. Op feitlik elke terrein van die lewe beleef bejaardes voortdurend verliese: liggaamskragte neem af; familie en vriende sterf - hulle leef voortdurend in die skadu 
van die dood. Gedagtes oor die dood is voortdurend deel van hulle denke. Die dood is enersyds vir die bejaardes 'n saak om na uit te sien op grond van die oorwinning van Christus en andersyds skep dit 'n onsekerheid op grond van die sonde wat deurlopend deel van ' $n$ mens se lewe bly. Die bejaarde fase kan ook beskryf word as die tyd van rekonstruksie. Die bejaardes kyk voortdurend terug op hulle lewenspad. Hulle vra voortdurend na die sinvolheid van hulle lewe wat agter die rug is. Die voortdurende besinning lei tot koersaanpassings: die goeie wat gedoen is, word verder uitgebou; die verkeerde word reggestel. Baie bejaardes beskik oor baie tyd en nog oor goeie verstandelike vermoëns. Hulle wil graag verder toegens word om hulle eie rol op 'n sinvolle wyse te vervul en om van diens te wees vir veral hulle kinders, kleinkinders, kerk en samelewing.

Volgens Peterson (1984:76) is 'self-directing' en 'problem solving' twee van die belangrikste aspekte waarmee gedurende die onderrig van volwassenes, rekening gehou moet word.

Namate persone opgroei, neem hulle gerigtheid en aangewesenheid op hulleself geleidelik toe. Kinders het behoefte aan 'n leersisteem waar hulle grootliks afhanklik van die onderwyser is. Ongelukkig word lidmate in 'n kerklike milieu groot, waar hierdie afhanklikheid van die voorganger ook van volwassenes verwag word en lidmate dink dat niks sonder die ampsdraers gedoen kan word nie. Sonder twyfel het navorsers vasgestel dat 'adult learners simply thrive best under conditions which promote, enhance, and develop self-directed learning' (Peterson 1984:76). In praktyk beteken dit dat die volwasse leerder by elke aspek van die leerproses, selfs by die keuse van temas, inhoude, doelwitte, onderrigwyses en evalueringwyses, betrek moet word.

Volwassenes word volgens Knowles (in Peterson 1984:74) veral deur drie aspekte gemotiveer vir leer: die genot wat hulle uit die leer put, omdat hulle baie beter oor hulleself voel; hulle behoeftes word tegemoet gekom en op die probleme waarmee hulle worstel, word antwoorde gevind. Daar bestaan 'n groot verskil in die motivering van volwassenes en kinders met betrekking tot leer. Kinders het behoefte aan leer omdat hulle ' $n$ bepaalde tema of saak wil bemeester. Volwassenes het eerder behoefte daaraan om die praktiese probleme waarmee hulle worstel, te oorwin.

When adults sense a problem in their own lives or communities, they are motivated to learning so that they may solve the problem. The problem may be major or minor; but adult learning does not take place in a vacuum. Because adults are very interested in the issues of live, and because their live experiences dominate their thinking, they approach learning in response to the life issues which confront them. Therefore, 
sensitivity to the issues in adult life will provide important insight for teaching adults. Being aware of the problems that adults face will help us to know both how to teach them and what to teach them.

(Peterson 1984:76)

Simpson (1992:104) sê opsommend in hierdie verband: 'Volwasse-leerders aanvaar vrywillig gesagsverhoudings, is probleem-, taak en prestasiegesentreerd, stel belang in persoonlike ontwikkeling, wil toepaslike dinge leer en soek terugvoer. Hulle is praktykgerig, bereid om opdragte uit te voer, gewillig om leerkontrakte aan te gaan en verlang duidelik uitgespelde leerdoelwitte'.

Die volwassene bevind hom in 'n wêreld waar 'n groot verskeidenheid vorme, norme en oortuigings funksioneer (Beukes 1995:17). Van die belangrikste lewensvorme wat vanaf die sestigerjare na vore gekom het, is: die waarheid staan nie meer vas nie; die Christelike godsdiens word slegs beskou as 'n godsdiens naas ander godsdienste; die belangstelling in die hiernamaals het geheel en al vervaag; die mens se behoftes het die bepalende geword en eksperimentering op feitlik elke terein kom voor (Steeneijer-Van Rij 1969:20). Op Suid-Afrikaanse bodem is dit veral Boshoff (1990), Vorster (1994) en Hendriks (1996) wat besondere bruikbare gegewens ten opsigte van die Suid-Afrikaanse samelewing na vore gebring het. Boshoff toon die volgende as feitlik algemene tendense van die Suid-Afrikaanse samelewing aan: enkelouers, afwesige vader en moeder, groot diversiteit in waardesisteme, teenwoordigheid van lidmate met wyd uiteenlopende beskouings, bevraagtekening en selfs omvergooi van tradisie, toeganklikheid van ander kulture en godsdienste en onsekerheid oor die toekoms. Die volgende wêreldtendense het volgens Vorster deel van die Suid-Afrikaanse samelewing geword: internasionalisme, sekularisme, postmodernisme en anti-institusionalisme. Hierdie verskillende ideologieë het tot gevolg dat die plaaslike opvoeders se norme nie meer geld nie, maar die denke van die voorste denkers van die buiteland; alles word al hoe meer verwêrelds; die bonatuurlike se invloed word al hoe kleiner; absolute norme bestaan nie meer nie en die stem van die kerk of van 'n instituut word net nie meer aanvaar nie. Hierdie tendense oordeel Vorster behoort die kerk en alle opvoeders as 'n geleentheid te benut en nie as 'n bedreiging te sien nie. Hendriks het aangetoon dat die grootste gedeelte van Suid-Afrika se Christene uit die swart gemeenskappe kom. As dit in aanmerking geneem word, beteken 'n deurlopende saamwees en gesprek tussen wit en swart gelowiges 'n feitlik alledaagse situasie. 


\subsubsection{Die onderwyser van die volwasse leerder}

Die onderrigproses is ' $n$ dinamiese gebeure tussen veral drie komponente: die onderwyser, die leerder en die leerstof (Dingemans 1986:208). Hierdie proses is dinamies omdat dit aan voortdurende verandering onderworpe is. Die leerder is voortdurend besig om te ontwikkel en die leerstof wissel voortdurend namate die leerders ontwikkel en die doelwitte verander. In die lig van hierdie dinamiese gebeure oordeel Peterson (1984:86) dat die onderwyser van volwassenes, waar nodig, oor 'n besondere vermoë moet beskik om te beplan en aanpassings. te maak. Leierskap beteken veral die vermoë om te begelei met die oog op presensie, visionering, fasilitering en energering. Dit beteken die leier-onderwyser moet iemand wees wat: God by mense verteenwoordig; mense help om vanuit die opstanding van Jesus Christus te lewe; self in staat is om binne gemeenteverband strukture te skep vir diens aan God, mekaar en die wêreld en om die energie in die gemeente te ontsluit met die oog op diens aan God, mekaar en die wêreld (Smit 1994:2). Die kerkonderwyser moet oor die nodige kennis en gesindheid ten opsigte van God en mense beskik en vaardigheid van die onderriggebeure (Beukes 1983:106). Simpson (1992:104) beskryf die onderwysers van volwassenes as persone wat in staat is om die leerders as selfstandige wesens te beskou en hulle menswaardigheid te respekteer. Hulle tree nie voorskriftelik op nie en gee redes waarom die leerinhoud gedek moet word. Hulle toon die nut van die leerinhoud aan en spel toepaslikheid uit. Hulle spel die kriteria en die verwagting vir evaluasie uit en klaar die tempo van leer uit. Hulle benut die kennis en die ervaring van die leerders. Hulle koppel, waar nodig, nuwe leerinhoude aan bestaande ervaring en wend die beginsels van die ervaringsleer aan. Die onderwyser van volwassenes itan elkeen in sy klas as ' $n$ 'potentially developing adult and therefore the teacher cannot be assumed to be developmentally superior to anyone else' (Allman, in Tight 1983:121). Na deeglike studie van verskillende leierskapstyle oordeel Nel (1987:52) dat die leier van 'n Christelike gemeente nie outokraties of demokraties is nie, maar Christokraties. Hoewel die meeste leiers 'n bepaalde dominante leierskapstyl het en van die onderwysers van volwassenes verwag word om 'n sterk persoonsgerigte styl te hê, skyn dit tog die beste indien hulle eerder ' $n$ styl het wat na gelang van die doelwitte van die les kan aanpas.

Dit is baie belangrik dat die onderwyser van volwassenes 'n Geesvervulde mens is wat die Bybelse voorskrifte in verband met kerklike leierskap uitleef, veral die voorskrif van die liefde. 'The teacher of adults must have a pastoral heart that has specific loving concern for each of his students. Students should come into the class and feel welcomed, valued, and loved by the teacher and the class' (Peterson 1984:83). 


\subsubsection{Die onderrigruimte en fasiliteite van die volwasse leerder}

Volwassenes is oor die algemeen so ingestel dat hulle enige situasie of geleentheid wil benut as leergeleentheid. Die kriteria vir die volwasse leerder is doeltreffendheid. Die andragogie oordeel dat volwassenes by hulle werk gewoonlik met 'n doeltreffende leerruimte en media te doen kry. Elke geleentheid waar ondoeltreffende fasiliteite benut word, lei by die volwassene tot 'n negatiewe ervaring. Die fasiliteite wat benut word, is deel van die leergeleentheid en wil as sodanig 'n funksie vervul. Die onderrigruimte en veral die onderrigmedia word benut, afhangende van die leerders wat ter sprake is, die doelwitte wat moet realiseer, die inhoud wat gekies word en die leergeleenthede wat benut word.

\subsection{Leergeleenthede}

Een van die basiese uitgangspunte van die andragogie is: 'adults, by their nature are learners. Learning is a very common aspect of adult life and a foundational desire. It is clear that adults are interested in education and want to learn' (Peterson 1984:73). Op grond van genoemde uitgangspunt maak Knowles (in Peterson 1984:74) die volgende onderskeid tussen pedagogie en andragogie, wat altyd in die onderrig van elkeen van hierdie kategorieẽ verreken moet word: In die onderrig van kinders is die leerlinge afhanklik van die onderwyser, hulle soek na kennis, die onderrigproses is onderwysergesentreerd, outoritêr, formeel en die onderwyser bepaal die doelwittte. In die geval van die andragogie is die leerders selfstandig, hulle is nie op soek na kennis nie, maar na die oplossing van probleme, die onderrigproses is nie onderwyser-gerig nie, maar leerder-gerig, Die behoeftes word deur die leerder uitgespel, die atmosfeer is informeel en die leerder word as selfstandige persoon gehanteer en geen outoritêre optrede kom voor nie.

Die onderwysers bepaal nie alleen die hoe en die wat van die onderrig nie, hulle doen dit saam met die leerders.

Within an andragogic approach a 'peer learning group', which includes the tutor, negotiates the curriculum, the objectives and the methods which will be used. They also negotiate decisions or questions regarding assesment and evaluation. Negotiation implies a sharing of power by all members of the group rather than an abrogation of power by the tutor; all members of the group contribute to decision making and the resourcing of learning. Method selection is based on decisions regarding the appropriateness for reaching a particular learning goal. 
Die andragogie onderskei tussen leerervaring en leergeleentheid. Die leerervaring beskryf die wyse waarop die leerder die inhoud beleef. Die leergeleentheid is die metode of die tegniek wat die onderwyser benut om die les aan te bied.

\begin{abstract}
Vanuit die vertrekpunt dat volwasse-leerders geleentheid gegee en gegun moet word om hulle potensiaal te ontdek en te ontwikkel, beredeneer Knowles (1987:173-176) die praktiese wyse waarvolgens die ideaal gerealiseer kan word. Die skep van leergeleenthede waarbinne leerervarings aan bestaande ervarings van individue sowel as die groep gekoppel kan word, vorm die struktuur waarbinne 'n proses van ontwikkeling aan die gang gesit word. Daarbenewens is dit belangrik dat die behoeftes van die leerders in aanmerking geneem word.
\end{abstract}

(Simpson 1982:88)

Dit is egter nie net die leerders se behoeftes wat die onderrigwyse bepaal nie, maar die leerder as geheel, die lesinhoud, die doelwitte, die onderwyser se insig en vaardigheid en die evaluasie (Peterson 1984:87). Peterson (1984:88) onderskei tussen 'impressional en expressional methods of teaching'. Die 'impressional method' is veral geskik en noodsaaklik waar bepaalde inhoude oorgedra moet word, en is as sodanig onontbeerlik in die kerklike onderrig van kinders en volwassenes. 'Impressional methods' betrek die leerder deur gehoor, gesig, gevoel, smaak of aanraking. Die doel van hierdie metodes is om inhoud an die leerders or te dra deur een van die sintuie. Proe en ruik is veral deur die antieke Semiete vir onderrig gebruik. Vandag word meer gefokus op hoor en sien en in ' $n$ mindere mate op gevoel (Peterson 1984:88). Die mees algemene 'impressional method' is die lesing. Entoesiasme van die aanbieder en benutting van ander effektiewe aanbiedings-tegnieke kan elke lesing steeds 'n besondere ervaring vir die leerders maak. Dit is nie meer ' $n$ vraag of onderrigmedia benut moet word of nie. 'It is already there, as it is in other aspects of society, in the experiental and environmental background of teacher and student alike. The real question is, how can we best use this pervasive technology for effective education' (Robert Heinrich, in Peterson 1984:93). Feitlik elke didaktikus bepleit die nut en die noodsaaklikheid van onderrigmedia.

Die besondere aard van volwassenes, veral hulle selfstandigheid, selfgerigtheid en geneigdheid om probleem-oplosser te wees, maak 'expressional methods' die aanvaarbaarste vir volwasse-onderrig. 'An expressional method involves the student in talking or acting. It allows him to express his feelings, understandings, or reactions pertinent to the class. When communication from the student is desired, an expressional method 
should be used' (Peterson 1984:99). Die volgende is van die algemeenste 'expressional methods': groepbesprekings, rollespel en debat (Beukes 1983:126). 'Na mate leerders verantwoordelikheid vir leer aanvaar, vervaag die behoefte aan lesings, videos en gedikteerde notas en ontwikkel hulle die behoefte aan groepbesprekings, groeptake, terugvoergeleenthede, rollespel en praktiese oefeninge, waarin teorie en praktyk gekoppel word, bestaande bevoegdhede benut word en die bereiking van doelwitte gedemonstreer word' (Simpson 1992:105). 'n Verskeidenheid aktiewe onderrigwyses moet benut word met die oog op die volwassene se verantwoordelikheid en betrokkenheid by die leergebeure. Selfs aktiwiteite buite die klas behoort benut te word met die oog op groter betrokkenheid. Die klasgebeure moet uit die gemeente-aktiwiteite voortkom en weer daarin uitmond (Richards 1975:95).

Soos by die meeste ander onderrigprogramme staan die formulering van doelwitte by die andragogie sentraal, en is evaluasie ' $n$ integrale deel van die onderriggebeure (Simpson 1992:104; Peterson 1984:87). Evaluasie vind veral plaas om te bepaal in watter mate die doelwitte gerealiseer het. Die evaluasie is deurlopend en verskillende strategieë word daarvoor benut. Naas deurlopende evaluasie van die lesse, moet die hele onderrigprogram van die gemeente ook deurlopend geëvalueer word. 'It is very important that we regularly evaluate all of the programs we have designed and which are there specifically to serve the adults and not to have the adults serve them' (Peterson 1984:83).

\section{SAMEVATTENDE GEVOLGTREKKING}

Binne 'n multikulturele opset vra elke verteenwoordigende kultuurgroep hantering volgens hulle eie aard. Hoewel individue uit verskillende kultuurgroepe deel is van die grootgroep, is dit nog steeds hulle wens dat hulle eie kultuurbeskouings eerbiedig word. Die een kultuur wil nie deur die ander verslind word nie. In die kerklike bediening word daar streng gesproke net met 'een saak' gewerk. 'n Multikulturele opset bring egter mee dat dit uit verskillende hoeke gesien word. Die andragogie hou rekening met elke individu se eie aard en behoeftes. Dit is dialogies van aard. Elke individu het in hierdie sisteem die reg om sy eie standpunt te huldig en dit te stel. Die verskillende standpunte en verskillende maniere van doen word so geakkommodeer dat die waarheid gedien word en die persoon wat die standpunt huldig, nie verworpe voel nie. Dit is veral die andragogie se mensgerigtheid bo saakgerigtheid wat dit vir die kerklike bediening geskik maak. Uit die aard van die saak sal die kerk hierdie wetenskap se resultate moet benut sonder prysgawe van teologiese uitgangspunte.

\section{Literatuurverwysings}

Albertyn, C F (red) 1974. Ensiklopedie van die wêreld, Deel 6, 368-370. Kaapstad: Printpak. 
Beukes, M J du P 1983. Kategese: 'n Handleiding vir kategete. Kital: Pretoria.

- 1994. Beskrywing en evaluering van verskillende kategetiese beskouings met die oog op die formulering van basisteorieë vir die kategese. HTS 50/1 \& 2, 211235 .

1995. Ontwikkeling van die kategese tot 'n familiale-gemeentelike geloofshandeling. Praktiese Teologie in Suid-Afrika 10/2, 13-27.

Bijlsma, R 1962. Kleine catechetiek. Nijkerk: Callenbach.

Boshoff, H 1990. Samelewingsveranderinge en die kerk in die negentigerjare: Moontlike implikasies. Potchefstroom: Instituut vir Toekomsstudies.

Coetzer, W H 1988. 'n Konsep bejaardebediening gebaseer op die aktiwiteitsteorie wat reg sal laat geskied aan die eiesoortigheid van die bejaarde met 'n gepaardgaande keuse ten opsigte van 'n ekklesiologiese vertrekpunt. Ongepubliseerde studiehandleiding, Sentrum vir Teologiese Navorsing en Toerusting, Universiteit van Pretoria.

Davenport, J \& Davenport, J A·1985. Knowles or Lindeman: Woud the real father of American andragogy please stand up? Lifelong Learning 9(3), 4-5.

Dingemans, G D J 1986. In de leerschool van het geloof, mathetiek en vakdidactiek voor catechese en kerkelijk vormingswerk, in Handboek praktische theologie. Kampen: Kok.

Doeser, M C 1983. De dialoog kritisch bezien. Baarn: Ten Have.

Firet, J 1977. Het agogisch moment in het pastoraal optreden. Kampen: Kok.

Fowler, J W 1981. Stages of faith, the pssychology of human development and the quest for meaning. San Franscisco: Harper \& Row.

Hendriks, H J 1992. Strategiese beplanning in die gemeente: Die beginsels en praktyk van gemeentevorming. Goodwood: Nasionale Boekdrukkery.

- 1996. Kerkspieël IV en NGK statistiek van die bevolking sensusse 1911-1991.

Ongepubliseerde - referaat gelewer tydens Praktiese Teologie Werkgemeenskap.

Jarvis, P 1987. Adult learning in the social context. London: Croom Helm.

Knowles, M S 1973. The adult learner: A neglected species. Texas: Gulf.

- 1984. Andragogy in action. San Francisco: Jossey Bass.

Louw, D A, Gerdes, L C \& Meyer, W F 1984. Menslike ontwikkeling. Pretoria: HAUM.

Louw, G J J 1981. 'n Temporaliteits pedagogiese verantwoording van opvoeding in 'n veelvuldige samelewing met besondere verwysing na 'multicultural education'. DEd-proefskrif, Universiteit van Pretoria.

Nederduitsch Hervormde Kerk van Afrika, 1995. Besluitebundel vir die 64e Algemene Kerkvergadering. Pretoria: NHKA. 
Nel, M 1987. Teologiese perspektiewe op gemeentebou. Pretoria: NG Kerkboekhandel.

1988. Fases in gemeentebou. Pretoria: NG Kerkboekhandel.

1994. Gemeentebou. Pretoria: Orion.

Lynch, J 1983. The multicultural curriculum. London: Batsford academic and educational Ltd.

Olivier, M 1982. Die katkisant, in Beukes, M J du P \& Geyser, P A (red), Ongepubliseerde referate gelewer voor die predikantevergadering van die NHKA in 1982.

Pelser, G M M 1990. Die bedieninge in die Nuwe Testament: 'n Ondersoek na historiese wording en prinsipiële regverdigbaarheid. Praktiese Teologie in SuidAfrika 5/1, 1-19.

Peterson, G A' 1984. The Christian education of adults. Cicago: Moody Press.

Pieterse, H 1993. Praktiese Teologie as kommunikatiewe handelingsteorie. Pretoria: RGN.

Prins, J M G 1992. Kommunikatiewe handelinge in diens van die evangelie: Implikasies vir kategese. Praktiese Teologie in Suid-Afrika 7/2, 137-147.

Richards, L O 1975. Christian education - seeking to become like Jesus Christ. Grand Rapids: Zondervan.

Schippers, K A 1982. Werkplaats catechese, doelbepaling en organisatie jongerencatechese. Kampen: Kok.

Simpson, C J A 1992. 'n Evaluering van andragogie as konsep binne die raamwerk van wetenskaplike konstrukte. Magisterverhandeling, Randse Afrikaanse Universiteit.

Simpson, C J A \& Lesing, B C 1992. Leerteoretiese basis van die andragogie. Journal of Industrial Psychology 17/1, 1-4.

Smit, A 1995. Nuut gedink oor leierskap in gemeentes. Pretoria: Lux Verbi.

Steenmeyer van Rij, M W 1969. Godsdienstige opvoeding in deze tijd: Benadering van 8-, 9 en 10-jarigen in de kinderdienste. Den Haag: Boekencentrum.

Tight, M 1983. Opportunities for adult education. Bristol: Biddles Ltd.

Van Staden, P 1995. Multikulturaliteit as sinvolle verskynsel en multikulturele bediening. Ongepubliseerde studieverslag or multikulturele gemeentes. Nederduitsch Hervormde Kerk van Afrika.

Van Uchelen, A C 1945. Het heilig onderricht der kerk. Amsterdam: Uitgewer onbekend.

Viljoen, C T 1995. Die praktiese implikasies van multikulturele onderwys. Woord en Daad, 19-23.

Vorster, K 1994. Die kerk in 'n nuwe konteks. Referaat gehou tydens interkerklike samesprekings van die drie Afrikaanssprekende susterkerke. 